\title{
The types and functions of code switching in a thesis defense examination
}

\author{
1Usman Kasim \\ 'Yunisrina Qismullah Yusuf* \\ 1Sri Rahayu Jumiati Ningsih \\ ${ }^{1}$ Department of English Education, Faculty of Teacher Training and Education, \\ Universitas Syiah Kuala, Banda Aceh, Indonesia
}

*Corresponding Author

Email: yunisrina.q.yusuf@unsyiah.ac.id

\begin{abstract}
This study investigated the acts of code switching by lecturers and student in thesis defence examination at a university in Banda Aceh, Indonesia. The study involved five participants (four lectures and one student) of the English Language Department. Data from recordings were used to analyse the types and functions of code switching that occurred during the defence. The types of code switching were analysed based on Poplack, and the functions of code switching were analysed based on the theories by Gumperz, Hoffman and Holmes. The result showed that there were three types of code switching found in 109 examples during the interactions between the lecturers and the student, they were: intra-sentential switching (77.06\%), inter-sentential switching (15.59\%), and tag switching (7.33\%). In term of the functions of code switching, 10 functions were identified from 68 switches, they were: addressee specification at $22.05 \%$, followed by interjections (16.17\%), loanwords (16.17\%), message qualifications (11.76\%), transfer of the subconscious markers (8.82\%), proper names (8.82\%), quotations (5.88\%), message reiteration (4.41\%), personalization versus objectification (2.94\%) and specific features of Islamic terms (2.94\%) as the least. It can be concluded that in this case, code switching allowed the participants achieve a wide range of important and interesting ends in their discourse during the thesis defence examination.
\end{abstract}

Keywords: Bilingualism; code switching; types; reasons; thesis defense; examination

Received: $\quad$ Revised: Accepted: Published:

2 March $2019 \quad 10$ May $2019 \quad$ 1 June $2019 \quad 31$ August 2019

\section{INTRODUCTION}

In a multilingual context, shifting or mixing codes with other languages among the speakers is a common practice; and this is typically called code switching. Moreover, code in this case means a system used for communication between two or more parties which can be a language, dialect, style or register (Wardhaugh, 2006). It is a strategy in the way speakers communicates with each other to achieve better understanding among them. This alternation of two languages is done within a single discourse, sentence, or constituent (Jamshidi \& Navehebraim, 2013). Crystal (2003) further says people who learn 
Kasim, Yusuf, Ningsih, EduLite: Journal of English Education, Literature, and Culture Vol.4, No.2, August 2019, 101-118 DOI: http://dx.doi.org/10.30659/e.4.2.101-118

English as a foreign language in a non-native speaking environment do not only need to know words, but they also need to know communication strategies. Choices about how code-switching manifest itself is determined by a number of social and linguistics factors. Additionally, many studies (Gumperz, 1982; McClure, 1981; Milroy \& Muysken, 1995; Myers-Scotton, 1993; Poplack, 1980; Romaine, 1995) have revealed that bilingual speakers use code switching as a valuable linguistic strategy to achieve certain communicative goals.

In the context of English as a foreign language, Macaro (2005, p. 63) argued that code switching in the classroom does not have the positive image of being "an asset and a valuable addition to their array of communicative strategies". This argument is supported by Littlewood and Yu (2011) who assumed that code-switching crowds out the target language and therefore has unfavorable effects on the learning process. Thus, educators often do not desire to do code switching in the classroom. Furthermore, Macaro (2005) summarizes the arguments against code switching in the FL classroom under five aspects: to code switch in the classroom means a recourse to L1 which is not desirable because the L2 classroom should aim at maximizing L2 input, avoidance of code switching warrants the absence of negative interference, avoidance of code switching impedes a return to unfashionable methods (i.e. grammar translation method, a method in which the target language is crowded out and L2 is taught without regard to language use in the 'real world'), and finally, avoidance of code switching is regarded as an indicator for 'good teaching', i.e. has a control function.

Nevertheless, there are pros and cons in the use of code switching in the EFL classroom. Some studies conducted by researcher have pointed out the types and functions of code switching in the results of their research. Ramos (2010), Mujiono, et al. (2013), Ibrahim, Shah and Armia (2013) and Sanchez (2015) have identified various types and functions of code switching in the EFL classroom contexts that benefited both the lecturers or teachers and their students. The switches made information given by the lecturers more understandable to the students, especially to those students who lack of English vocabulary. It also brought relaxing environment to students when the learning situation got tenser in which code switching could bring humor into their classroom discourse. Many research studies argue that the strategy of code-switching can be a useful tool in assisting English language teaching and learning process. Skiba (1997) states that code switching helps the senders transfer the information to the receivers effectively. In an L2 learning environment, although the exposure to the target language (L2) can help learners to achieve success, this exposure may not always work effectively in every context (Cook, 2001; Ellis, 1994; Richards \& Rodgers, 2001). Many factors affect the learning success, for example, English-only classroom leads to frustration and anxiety because the learners cannot get enough and proper comprehensible input. Consequently, code-switching could be a strategy used by teachers to help learners. Various positive functions of code-switching, such as explaining new vocabulary, grammar, and new concepts and relaxing learners would improve the learners' comprehensible input during the learning process (Ahmad \& Jusoff, 2009). 
In this study, we explored the acts of code switching by a university student in Banda Aceh with his lecturers during his thesis defense examination. In Aceh province, people speak more than one language because basically they are a bilingual or multilingual society where Acehnese is mostly spoken by the people as their mother tongue. Even each Acehnese sub-group has its own language and dialect that represents their different identities in social life (Yusuf, 2013). Aceh is also a part of Indonesia; therefore, Indonesian is the national language of the country. They master the two languages by the time they communicate both in oral and written forms. Meanwhile, in the academic context, students learn English as a foreign language as well. And so, it is important to note that university students who study in institutions in Banda Aceh come from different regions all over Indonesia, not just the Acehnese, who have different mother tongues and culture backgrounds. Shifting and mixing their languages is a common hearing in daily conversations.

Furthermore, when using English, many Acehnese students undergo interferences from their Acehnese and Indonesian. As stated by Berthold, Mangubhai and Batorowicz (1997), interference may be viewed as the transference of elements of one language to another at various levels, including the phonological, grammatical, lexical and orthographical levels. In our case, students can speak in three or four languages at once: Acehnese, Indonesian, English and Arabic. The Acehnese are Muslims; therefore, some Islamic expressions are also often used in their daily conversations. Examples extracted from our preliminary observations especially of the Acehnese students' discourse in Indonesian (underlined), Acehnese (italicized), Arabic (bolded) and English are such as 'Thank you, Pak' [Thank you, Sir], 'Assalamu'alaikum, uroe nyoe na mata kuliah' [Peace be upon you (Islamic greetings), there is a class today], 'Peu na event di lantai dua, ya?' [Is there is an event on the second floor?], 'By the way, rencana kemana kita weekend ini?' [By the way, where should we go this weekend?], etc. From the examples, it can be seen that they try to communicate in a certain way with their own style to keep a good relationship with their interlocutor(s), and also among the ways to introduce their social identity through the language.

The results of this research is hoped to be useful for the researchers who are interested in the sociolinguistics studies, especially in the practice of code switching by multilingual speakers. Code switching is a common communication skill among bilinguals and is known to be a naturalistic occurrence among these speakers (Macaro, 2014). Nevertheless, to understand the types and functions of this code switching to the speakers is more essential because they underline the possible implications of code switching for education, especially in countries that teach foreign languages in their education system, such as Indonesia with English and also Arabic, and uses these languages in their formal and informal communication. 
Kasim, Yusuf, Ningsih, EduLite: Journal of English Education, Literature, and Culture Vol.4, No.2, August 2019, 101-118 DOI: http://dx.doi.org/10.30659/e.4.2.101-118

\section{METHOD}

\section{Participants}

In this study, a qualitative research approach was used to investigate the types and functions of code switching in an academic context, specifically in a thesis defense examination. Hancock (2002) considered this approach as the most appropriate which usually focuses on small number of individual in order to analyze the behavior, experiences and opinion of the participant(s).

The participants of this study were one student and four lecturers from the English Education Department, Faculty of Teacher Training and Education, Syiah Kuala University, Banda Aceh. The situation was in a thesis defense examination. This examination is aimed for students as a condition in completing their study by doing an educational research after a 4 year-study at the department.

\section{Instruments}

In the process of collecting data, a cellular phone (i.e. Iphone $5 \mathrm{~s}$ type), which is equipped by 16 GB internal memory, was used to record the dialogues between the students and lecturers during the examination. A video camera was also situation at the corner of the room to record events that could be missed from the phone recording. There were done with the consent from the participants. The two hour recordings were further transcribed by using the transcriptions mark-ups adapted from Yusuf (2009).

There were four languages found in the recording: English, Indonesian, Acehnese and Arabic. In this paper, the transcription of English was typed in normal text, underlined for Indonesian, italics for Acehnese and bold for Arabic. The Acehnese orthography follows the latest one proposed by Pillai and Yusuf (2012). Meanwhile, people's names mentioned by the participants in the recording were changed in the report of this paper for research ethical purposes.

\section{Data Analysis Procedures}

After collecting the data, they were analyzed by following several steps taken from Creswell's theories (2009): prepared data for analysis, which included the transcription after recording, re-read and comprehended all data related to types and functions of codes witching used by the participants, coded and classified the data one by one into types of code switching as proposed by Poplack (1980) and functions of code switching as proposed by Gumperz (1982), Hoffman (1991) and Holmes (1992). Poplack (1980) classified the types of code switching into three categories: intra-sentential code switching, intersentential code switching and tag switching. Finally, conclusions are drawn to enlighten the readers on the code switching phenomenon in the context of an EFL thesis defense examination between the student and his lecturers.

\section{RESULTS AND DISCUSSION}

This section presents the results into two sub-sections; the findings on the types of code switching and the findings on the functions of code switching 
conducted by the student and lecturers in an EFL thesis defense examination. In data display, Lc1 refers to Lecturer 1, Lc2 refers to Lecturer 2, and so forth. Meanwhile, the student is coded with St.

\section{Types of code switching}

The occurrences of the types of code switching are as shown in Table 1.

Table 1: Percentage of types of code switching used by the student and lectures in an EFL thesis defense examination

\begin{tabular}{lll}
\hline Type of code switching & Frequency & Percentage (\%) \\
\hline $\begin{array}{l}\text { Intra-sentential code } \\
\text { switching }\end{array}$ & 84 & 77.06 \\
Tag switching & 17 & 15.59 \\
Inter-sentential code & 8 & 7.33 \\
switching & 109 & 100 \\
TOTAL of occurrences & & \\
\hline
\end{tabular}

Table 1 shows that the occurrences of code switching in terms of types in this study were 109 times. Specifically, $77.06 \%$ were intra-sentential code switching, $15.59 \%$ were tag switching, and $7.33 \%$ were inter-sentential code switching. Furthermore, Table 3 displays the frequency of types of code switching done by every participant.

Table 2: Percentage of code switching used by each participant

\begin{tabular}{llllll}
\hline Participant & $\begin{array}{l}\text { Intra- } \\
\text { sentential } \\
\text { code } \\
\text { switching }\end{array}$ & $\begin{array}{l}\text { Inter- } \\
\text { sentential } \\
\text { code switching }\end{array}$ & $\begin{array}{l}\text { Tag } \\
\text { switching }\end{array}$ & $\begin{array}{l}\text { Total } \\
\text { Frequency }\end{array}$ & $\begin{array}{l}\text { Total in } \\
\text { percentage } \\
\text { (\%) }\end{array}$ \\
\hline Lc1 & 12 & 0 & 0 & 12 & 11 \\
Lc2 & 11 & 0 & 4 & 15 & 13.76 \\
Lc3 & 50 & 7 & 8 & 65 & 59.63 \\
Lc4 & 0 & 0 & 0 & 0 & 0 \\
St & 11 & 1 & 5 & 17 & 15.59 \\
Total & 84 & 8 & 17 & 109 & 100 \\
\hline
\end{tabular}

Based on Table 2, Lc3 had the highest percentage (59.63\%) in switching the language and the second highest percentage was St (15.59\%). From the recording, we found that Lc3 had a long discussion with St regarding his study. The language used by Lc3 was mostly in English but in the middle of the conversation, he changed the code into Indonesian and Acehnese. They were more interactive because Lc3 was the first examiner in the thesis defense and needed more information related to St's research. St was supposed to answer his questions in English, but St had politely requested to Lc3 that he answered most of the examiner's questions in Indonesian for better clarity and understanding. This was when most of the code-switching occurred. The third person who conducted the most code switching was Lc2 (13.76\%), she was the second supervisor to St. She has the same role with Lc1 who was the first supervisor who conducted code switching as much as $11 \%$. They did not interact much with St during the defense; perhaps this caused their lower percentages of code switching during the oral examination. Lc4, as the second examiner to St's oral examination, had $0 \%$ of code switching because he spoke in full English during the examination. 
Kasim, Yusuf, Ningsih, EduLite: Journal of English Education, Literature, and Culture Vol.4, No.2, August 2019, 101-118 DOI: http://dx.doi.org/10.30659/e.4.2.101-118

\section{Intra-sentential code switching}

The most occurred type of code switching from the data is intra-sentential code switching, it is as much as 76.36. Intra-sentential switching allows for an impression that speakers are inadequately proficient in a language to finish what they want to say. It is a more intimate type than inter-sentential and tag switching since both the code switched segment and those around it must adapt to the syntactic rules of both languages (Poplack 1980). The followings are some examples of intra-sentential code switching conducted by the student and lecturers during the defense found in the data. D refers to data, thus D1 is the first data for display in this section, and so forth.

D1 St: In collecting data/my/collecting data/maybe err I just faced the students err do not know anything about the learning style and they susah untuk diarahkan//Istilahnya what/err apalagi waktu saat itu the last semester. [In collecting my data, collecting data, maybe err, I just faced the students err did not know anything about the learning styles and they were difficult to be directed. Such as, what, err even at that time in their the last semester]

Lc3: Okay//Question saya/pada "generally not aware and know" / Kalau pakai "and" artinya dia/they are "generally not aware and they are" err "generally not know" atau "generally know"? Apa maksudnya? [Okay. My question/ is in "generally not aware and know". If you use "and", it means, he, they are "generally not aware and they are" err "generally not know" or "generally know"? What do you mean?)]

In D1, the intra-sentential code switching can be seen in St's utterances. Here, he started the sentence in English and then he switched into Indonesian to complete his sentence. Similarly, this can also be seen to be done by Lc3, where the lecturer started off in English and then switched into some Indonesian phrases to get to the point of his question to the student.

\section{Tag switching}

Tag switching was the second type that occurred in the data, which was as much as $15.45 \%$. Tag switching is when tags are put in different parts in an utterance. This is because tags have "no syntactic constraints, they can be moved freely, and they can be inserted almost anywhere in a discourse without violating any grammatical rules" (Poplack, 1980, p. 589). Four categories of tag switching in the data were found, they are: Indonesian and English, Indonesian and Acehnese, English and Indonesian, and English and Acehnese

\section{Tag switching between Indonesian and English}

D2 St: Do not/ $\underline{\mathrm{Pak}}$ ya? [Do not, is it, Sir?]

D3 Lc2: I mean err/closely/close meaning, lah. [I mean, err, closely, close meaning, lah (particle)]

D2 shows that St conducted tag switching in Indonesian. He inserted the word "Pak, ya?" [Is it, Sir?] after the utterance of "Do not". While in D3, Lc2 started the utterance by using English and then inserted the particle lah in Indonesian. This particle bears many functions; depending on the context it is 
used. Among them are to emphasize or enquire, to disagree or repair, to persuade, to soften the effect of an utterance and to compromise (see Yusuf, 2009).

\section{Tag switching between Indonesian and Acehnese}

D4 Lc2: Kleu-èp/ya. [Slow, yes]

D4 shows that Lc2 conducted tag switching by starting her sentence in Acehnese, kleu-èp [slow] and inserted the tag ya [yes] in Indonesian.

\section{Tag switching between English and Indonesian}

D5 Lc3: Okay/sebelum itu coba katakan bahasa ini/... [Okay, before that, say this language...]

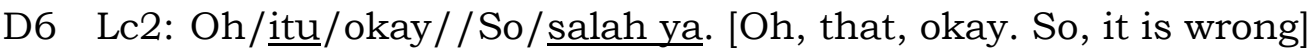

D5 and D6 display that Lc3 and Lc2 conducted tag switching in English and then switched into Indonesian. Lc3 in D6 inserted the word "okay" as the tag in English before completing his utterance in Indonesian. While in D7, Lc2 inserted "okay" and "so" between Indonesian.

\section{Tag switching between English and Acehnese}

D7 Lc2: Lagèe aneuk yèe/lagèe aneuk yèe/you know. [Like, like a baby shark, you know]

D7 shows that Lc2 started her utterance in Acehnese, and then she inserted the phrase "you know" as the tag to complete the utterance.

\section{Inter-sentential switching}

The type of code switching that occurred least in the data was inter-sentential switching, with $8.18 \%$ of occurrence. Inter-sentential switching covers "a switch occurs at a clause or sentence boundary where each clause or sentence is in a different language" (Romaine 1995, p. 122). To this switch, a greater fluency in both languages is required than tag switching since major parts of the utterance must conform to the rules of both languages. Examples from the data are shown below.

D8 Lc3: Yeah, okay. But, you know/you know your problem. Walaupun kami ndak perlu jawaban/belum tentu perlu jawaban disini ya. [Yeah, okay. But, you know, you know your problem. Even though we don't need the answer, not sure (if we) need the answer here]

D9 Lc3: 'Yang meuröt leumo tumbôn'. Do you understand? ['A fat cow still seeks grass to eat'. Do you understand?]

In D8, Lc3 started his utterance in English but then switched into Indonesian. This is similar to D9, where Lc3 started his sentence in one language (i.e. Acehnese), and continued his next sentence in another (i.e. English). Accordingly, from the examples, it can be concluded that the participants in this study switched their language from one to another (i.e. Indonesian to English, English to Indonesian and Acehnese to English) which they thought could be useful to repeat, justify or clarify their statements so 
Kasim, Yusuf, Ningsih, EduLite: Journal of English Education, Literature, and Culture Vol.4, No.2, August 2019, 101-118 DOI: http://dx.doi.org/10.30659/e.4.2.101-118

that the interlocutors can better understand the messages that they try to put forward.

\section{Functions of Code Switching}

The nine functions of code switching as proposed by Gumperz (1982), Hoffman (1991) and Holmes (1992) were found in the data. One more function found in data was also added to the list, which are specific features of Islamic terms. Table 3 lists the findings from the most to least occurred function discovered in the data.

Table 3: The functions of code switching in thesis defense examination

\begin{tabular}{llll}
\hline No & Conversational functions & Frequency & Percentage (\%) \\
\hline 1. & Addressee Specification & 15 & 22.05 \\
\hline 2. & Interjections & 11 & 16.17 \\
\hline 3. & Loanwords & 11 & 16.17 \\
\hline 4. & Message Qualifications & 8 & 11.76 \\
\hline 5. & Transfer of the Subconscious Markers & 6 & 8.82 \\
\hline 6. & Proper Names & 6 & 8.82 \\
\hline 7. & Quotations & 4 & 5.88 \\
\hline 8. & Message Reiteration & 3 & 4.41 \\
\hline 9. & Personalization Versus Objectification & 2 & 2.94 \\
\hline 10. & Specific Features of Islamic Terms & 2 & 2.94 \\
\hline & Total & 68 & 100 \\
\hline
\end{tabular}

From Table 3, it showed that the function as addressee specification received the highest percentage at $22.05 \%$, and this is followed by interjections $(16.17 \%)$ and loanwords (16.17\%), and then message qualification $(11.76 \%)$, transfer of the subconscious markers (8.82\%), proper names $(8.82 \%)$, quotations $(5.88 \%)$, and the least were message reiteration $(4.41 \%)$, personalization versus objectification $(2.94 \%)$, and specific features of Islamic terms. Explanation on the examples found in the data is in the following subsections.

\section{Addressee specification}

The function of the switching is to draw attention to the fact that the addressee is being invited to participate in the exchange (Gumperz, 1982). In addressing the lecturers, the student used the word Pak [Sir or Mr.] and Ibu [Ma'am or Mrs./Ms.] to address them, while the lectures used the word "you" or "name of the student" to address him (i.e. Ahmad). The lecturers addressed each other with $\underline{\mathrm{Pak}}$ or Ibu for politeness. Here are the examples:

D10 Lc1: So this is quite new/yeah/so/congratulation on that Ahmad/so/now me move on to your examiners/Pak FM? [So this is quite new/yeah/so congratulation on that Ahmad/so now we move on to your examiners/Mr. FM?]

Lc3: Alright, Ms. YY. [Alright, Ms. YY]

D11 Lc1: Okay thank you, Pak BD. Now your last feedback and questions will be from your supervisor, Ms. YN, okay.

In D10, Lc1 introduced one of the examiners in the thesis defense by addressing him with $\underline{\mathrm{Pak}}$ even though she was speaking in English. Following this, Lc3 had replied by addressing her with "Ms. YY". Similar to Malay, in 
face-to-face interaction a superior or senior may use personal pronouns when addressing an inferior or junior but the reverse is considered unacceptable (Yusuf, 2009). D10 reflects the case, in which an younger lecturer had called her senior with $\underline{\mathrm{Pak}}$, and this is something considered more polite in their culture, regardless of the language they speak since this habit has been taught to them since childhood. Nevertheless, she had addressed the other lecturer in the room who was with the same age with her with "Ms." (see D11), not with $\underline{\mathrm{Ibu}}$.

Meanwhile, there were many times when the lecturers addressed the student with "you". Suan (1990) have noted the interesting case of transfer when Malays use the English personal pronouns "I" and "you" while speaking Malay with their Malay interlocutors. But this only applies to addressing someone who is younger. Correspondingly, this also happens to Indonesian speakers in this case. Examples where the lecturers frequently addressed "you" to the students while speaking in Indonesian are as the following:

D12 Lc2: Yeah//My special thank you//Yeah/siapa yang you thank disini? [Yeah. My special thank you. Yeah, who do you thank here?]

D13 Lc3: Berani/You berani mengatakan itu? Berani? [Brave. Are you brave enough to say that? Are you?]

In examples D12 and D13, it is assumed that the lecturers addressed the student with "you" in their Indonesian sentences to emphasize the point of her question (see D12) and to express his disappointed feeling toward the student because he was not confident enough to say that the thesis was important to the reader (see D13).

\section{Interjections}

In interjections, the switch is to mark an interjection or sentence filler to get the attention of the interlocutor; this function is similar to tag-switching (Romaine, 1995). Romaine (1995) rationalizes that interjection is similar to tag switching. It is a part of speech that shows the emotion or feeling of the speaker which has no meaning but has function to be analyzed. An example from the data is as in D19.

D14 Lc4: Are you okay?//Actually I don't have any question/Um karena/err/because most of the suggestions were already given by Ms. YY//You see the um/what do we call this?/Err the control form//There were only five consultations and everything was done//Voila! Err but there were times when you disappeared for two months and then one month/yeah. [Are you okay? Actually I don't have any question because most of the suggestions were already given by Ms. YY. You see, what do we call this? The control form? There were only five consultations and everything was done. Voila! But there were times when you disappeared for two months and then one month. Yeah.]

Interjection can also be said as sentence fillers which functions to express strong feelings or better expressions and clarification in order to get attention from the listener(s) (Gumperz, 1982). In D14, the use of "um" and "yeah" can be regarded to express the lecturer's strong feeling or concern 
Kasim, Yusuf, Ningsih, EduLite: Journal of English Education, Literature, and Culture Vol.4, No.2, August 2019, 101-118 DOI: http://dx.doi.org/10.30659/e.4.2.101-118

towards the student's time of completing his thesis. Meanwhile, "err" were used to make clarifications and "voila" were to provide better expressions towards his statements. Some interjections indicate that the speaker is thinking of something, giving hesitation or making corrections before making the next statement as well. In D14, we can see that Lc4 started off in English and in the middle of his speech, he blurted out an Indonesian word karena [because] and provided an interjection "err" before he switched his next speech back into English. "Err" is an interjection typically found in English, whilst its equivalent in Indonesian or Acehnese would be eh.

\section{Loanwords}

Loanwords can also be called borrowed words or borrowing. Gumperz (1982) state that borrowing means introducing single word items or idiomatic phrases from one language to another. From the data, some loanwords used by the participants are:

D15 Lc3: Yeah, this is okay/nothing is wrong with this//I like this//Yeah/you err/apa namanya ini/err mengambil suatu inisiatif ya/ [Yeah, this is okay, nothing is wrong with this. I like this. Yeah, you er, what do you call it, er, you took an initiative.]

D16 Lc2: Kalau pada yang positif sudah betul/'there is a significant'// Pada negatif tidak bisa. [If on the positive, yes, 'there is a significant'. But not for the negative.]

D17 St: Oke/koreksi. [Okay, correct it.]

D18 Lc3: Ini harus dicabut dari/artikel//apa/jurnal/ya//Cabut aja. [This has to be withdrawn from the article, ah, journal. Withdraw it.]

From the examples above (D15-D18), it can be analyzed that the loanwords of inisiatif, positif, negatif, koreksi, artikel and jurnal were assimilated from words 'initiative', 'positive', 'negative', 'correction', 'article' and 'journal' in English.

\section{Message qualification}

As stated by Gumperz (1982), message qualification helps the speaker to better understand the message. It is to qualify a previously mentioned statement which can happen at level of the sentence, clauses and phrases level. An excerpt from data is as the following:

D19 Lc3: Oh/'from being thought'//Iya?//Saya malah berpikir/saya pikir dari 'teach' menjadi 'taught'/Bukan? Dari/dari 'diajarkan'//[Oh, from 'being thought'? Really? I thought (the word) is from 'teach', which becomes 'taught'. Isn't it? From 'being taught'.]

St: Memang bukan/memang bukan 'taught' yang dari 'mengajar' itu. [It is not 'taught' from the word 'teach'.]

Lc3: Jadi dari 'think' ini? [Is it from 'think' then?]

Lc1: Mestinya tidak ada 'being' ya? [Then there should not be 'being' there, right?] 
Lc3: Tidak ada//Kalau 'being' menjadi kalimat pasif ini maksudnya//Jadi bukan 'from being thought' ya//Jadi//From cognition? Ya//Mungkin yang dimaksud disini ya 'from cognition' bukan 'from being thought'. [No, if 'being' is added it means that it is a passive sentence//So this is not 'from being thought'. So, from cognition, perhaps? Yes, maybe you meant to write 'from cognition', not 'from being thought'.]

From the excerpt in D19, Lc3 asked the meaning of 'from being thought' to St. Based on the correct grammatical structure, the phrase should be 'from being taught'. Lc3 switched his language into Indonesian to qualify the previous incorrect grammar by St so St could better understand his intention. St convinced his examiner that the word he meant was from the base word 'think' and not 'teach'. If that was the case, Lc1 added it that St was supposed to delete word 'being' and finally Lc3 made his last argument to qualify and correct the mistake made by St in his thesis. This function of code switching helped the student to better understand his mistake so that he would not repeat it in the future.

\section{Transfer of the subconscious markers}

Two markers transferred subconsciously were from the recording, they are the insertion of particle lah and the use of ya. It is common in Indonesia to use the particle lah in sentences or utterances. According to Indonesian grammar, lah is used to emphasize a statement and it is always attached to the preceding word. When Indonesians and Malaysians speak English, it is a habitual expression to insert it, typically, at the end of their English sentence (Yusuf, 2009). An example from data is:

\section{D20 Lc2: Lagèe aneuk yèe. [Like a baby shark.]}

Lc3: Do you know what that means? (asks St)

Lc2: Teubit tamong (laughing). [In and out (laughing).]

St: Ahh//no (laughing). [No (laughing)].

Lc3: Restless lah.

St: Oh.

Lc3: Yup. When we say in the Acehnese proverb/lagèe aneuk yèe/it means restless lah. [Yup, when we say in the Acehnese proverb, lagèe aneuk yèe, it means restless.]

In D20, Lc2 and Lc3 had a discussion to describe the students' attitude toward his thesis. Lc2 referred St as such as aneuk yèe 'baby shark' that moves teubit tamong 'in and out', as the Acehnese say it. Then Lc3 asked what the meaning of that Acehnese phrase to St. When St did not know the answer, meaning, Lc3 used the particle lah to emphasize his answer. Meanwhile, the word ya means 'yes' in English, but it not always used as agreement. In Indonesian, the word ya can be used as a jargon to express agreement or justify something, to ensure, or to emphasize in questioning. It can be a subconscious marker in daily life for the speaker (Yusuf, 2009). Some examples found in data with ya functioning differently are as the following. 
Kasim, Yusuf, Ningsih, EduLite: Journal of English Education, Literature, and Culture Vol.4, No.2, August 2019, 101-118 DOI: http://dx.doi.org/10.30659/e.4.2.101-118

D21 St: Tidak baca semua buku. [I did not read all the books.]

Lc1: Very honest, ya. Very honest.

In D21, Lc1 used ya to seek St's agreement about his honesty that he did not read the entire books for his thesis. Lc1 employed ya to emphasize his statement that might mean being sarcastic or to quipped the student about his honesty.

D22 Lc3: Bukan/bukan 'there is no a significant' ya, there is 'no significant' saja. [No, it is not 'there is no a significant', 'no significant' is enough.]

While in D26, Lc3 used the word ya to correct St about his incorrect sentence in the thesis and provided him with the correct one.

D23 Lc3: Is 'aware' a verb?

St: Verb.

Lc3: Kenapa pakai 'to be' kalau begitu ya? [Then why do you use 'to be'?]

From the conversation above in D23, the use of ya was to emphasize in questioning about St's incorrect use of grammar in his writing.

\section{Proper name}

Proper name can also be called as technical terms which have some reason when conducted by speaker. As cited by Yusuf (2009) from Suan (1990) proper name is expressing ideas adequately by maintaining the original language of the terms. The author found some technical terms that used by the participant to express the word that have no proper meaning in other languages. They can be spoken correctly in their own language. Here are the examples.

D24 Lc3: Why is this research important? What is it so interesting? You know, this research will make you a Sarjana, right? During our time, this

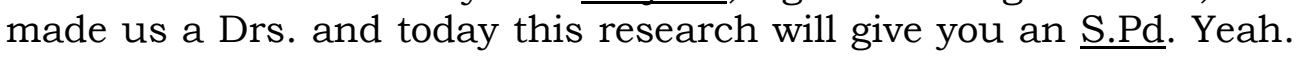
So what is so good about this research?

In D24, the words Sarjana (Bachelor's degree), $\underline{\text { S.Pd. (the title for Sarjana }}$ Pendidikan or Bachelor of Education) and Drs. (Doktorandus (originally from Dutch), which means an academic title according to the pre-Bachelor-Master system) are common technical term in Indonesian for a Bachelor's title.

\section{Quotations}

Gumperz (1982) describes quotations as the code switch that contains direct quotation or reported speech. This is shown in the examples below.

D25 Lc3: Okay//Itu yang saya tanyakan atau saya koreksi, kan?// Sekarang, dalam bulan puasa ni supaya banyak pahala/err Ahmad harus berikan sesuatu pada kami/ya. Ya//Sekarang tutup ini/oke tutup//Berikan sesuatu pada kami//Seperti/ "Pak, you know, my research is very interesting. This is the best one..." [Okay. That is the one that I asked (earlier) and corrected, right? Now, in this Ramadhan month, so that you will receive many rewards (from God), 
err Ahmad (you) must give us something. Yes. Now close your defense. Give something for us. Like, "Sir, you know, my research is very interesting. This is the best one..."]

St: [Laughing] Baik, Pak. My research is very interesting. This is the best one because I am the first one to research this topic at the school under study.

In D25, it is seen that Lc3 encouraged St to present the significance and importance of his research to the board. He provided an example of introduction to St by saying "Pak, you know, my research is very interesting. This is the best one..." and St had quoted him by repeating it in his sentence "My research is very interesting. This is the best one..." even though he had started his sentence off in Indonesian, "[Laughing] Baik, Pak" [[Laughing] yes, Sir]. And thus, the function of quotation here was to directly quote someone, in this context, St directly quoted his lecturer, Lc3, to sustain the originality of his suggestion.

Holmes (1992) also mentions that another related reason for switching is to quote a proverb or a well-known saying in another language. In this case, the author found some quotations to express a proverb used by the participants. For examples:

D26 Lc2: Yup//When we say it in Acehnese, there is a proverb lagèe aneuk yèe//it means 'restless'.

D27 Lc3: Kalau yang tadi kesibukan/kata kesibukan err justru orang mengatakan kalau Ibu tadi menggunakan/apa/proverb Bahasa Aceh/saya tambah satu lagi/semakin sibuk orang semakin banyak yang/semakin banyak pekerjaan/semakin banyak yang dicapai sehingga orang Aceh mengatakan 'yang meuröt leumo tumbôn'. [Before this, (you) were busy. The word 'busy', err to other people, if I had used an Acehnese proverb, I would add one more (to it). The busier one gets, more work then must be done, and more things will be achieved, and so the Acehnese say 'a fat cow still seeks grass to eat']

The proverbs lagèe aneuk yèe [restless] and yang meuröt leumo tumbôn [a fat cow still seeks grass to eat] are specifically found in the Acehnese language. These were addressed by the lecturers towards the student's attitude in writing his thesis. In D26, Lc2 conversed in English but then switched to Acehnese to quote the original phrase in the language. Similarly, in D27, Lc3 discussed the students' attitude in Indonesian and also switched to Acehnese to present the proverb. These switches did not mean that the lecturers were not sufficient in English or Indonesian; however they wanted to make sure that they provided the exact proverbs as said originally in its language to avoid inaccuracies.

\section{Message reiteration}

The function of reiteration is to repeat the message from one language to another language, either literally or in somewhat modified form (Gumperz, 1982). It commonly happens in conversation and found in literal or modified 
Kasim, Yusuf, Ningsih, EduLite: Journal of English Education, Literature, and Culture Vol.4, No.2, August 2019, 101-118 DOI: http://dx.doi.org/10.30659/e.4.2.101-118

form to clarify understanding between speakers. Here are the data found from the recording.

D28 St: Studying kan dari belajar, $\underline{\text { Pak} / f r o m ~ e x p e r i e n c e / d a r i ~}$ pengalaman/dan juga dari pemikiran mereka. [Studying is also from learning, Sir, from experience, from experience, and also from their thoughts].

D29 Lc2: But actually/err/to be honest/you are one of the students that I found very easy to supervise//I mean I don't find any difficulty in understanding your thesis//Err/it is beautifully written and then/um/every input/err/we give to you/err/you could do it//Yeah? But/the problem is you are kind of like a baby shark//You know baby shark?//Aneuk yèe [laughing]/teubit tamong. [But actually to be honest, you are one of the students that I found very easy to supervise. I mean I don't find any difficulty in understanding your thesis. It is beautifully written and then every input we give to you, you could do it. Yeah? But the problem is you are kind of like a baby shark. Do you know baby shark? Baby shark [laughing] going in and out.

In D28, St repeated the phrase "from experience" to Indonesian dari pengalaman that has a function as a translation. Another function as a translation is shown in D29, where Lc2 said, "you are kind of like a baby" to St. She translate the utterance into Acehnese to make sure that St understood because it is usually said in the Acehnese proverb aneuk yèe. In Acehnese, when a person is referred to this name, it means that the person is smart or clever but not serious in doing the things he needs to do.

\section{Personalization versus objectification}

Personalization versus Objection refers to the change of codes when talking about oneself as opposed to talking about other people (Gumperz, 1982). The switching's function is to indicate the distinction between opinion and fact that reflects whether a statement is of the speaker's opinion or refers to a specific instance. In this case, the example is:

D30 Lc2: Yeah, okay//But you know/you know your problem. Walaupun kami tidak perlu jawaban/belum tentu perlu jawaban disini ya/ / Mungkin ada hal tertentu/like ah/do you know actually why or what made you like that?// Sebab mungkin ada hal tertentu sebenarnya/seperti "karena ibu ndak tau kalau saya subuh-subuh itu kerja. Ya. Sebelumnya saya sudah keluar. Kalau saya tidak kerja ini saya tidak bisa kuliah". [Yeah, okay. But you know your problem. Even though, maybe, we do not need to know the answer here. Maybe there was something (that you can tell us). Like do you know actually why or what made you like that? Maybe there was something (that you can tell us), such as "because, Ma'am, you do not know that I actually have to work very early in the morning. Yes, before (sunrise) I already leave the house (because) if I don't work I cannot finish my studies".] 
In example D30, Lc3 was curious why St had difficulty in completing his thesis in time, and then he switched the language into Indonesian to give his opinion to answer his question. This was because he was trying to probe the student to speak and tell them the reason. There were opinion and fact in this utterance. Lc3 gave his fact about the students' problem in, "Yeah, okay. But you know your problem", and then he switched his language into Indonesian to provide his opinion on why St put off in completing his thesis.

\section{Specific features of Islamic terms}

As found in the recording the utterance Assalamualaikum warrahmatullahi wabarakatuh which means "Peace be upon you and Allah's mercy and blessings" is used in the opening and closing of the thesis defense examination. Such as in this closing statement:

D31 Lc1: Okay, Ahmad, so, congratulations for defending your thesis. We wish you the best for your future, ya. Thank you to your examiners for their very constructive and good feedback and suggestions. Assalamualaikum warrahmatullahi wabarakatuh.

\section{DISCUSSION}

The first research question was on the type of code switching employed in a thesis defense examination between a student and his four lecturers. The results showed that a total of 109 switches were found in three types of code switching. They are intra sentential switching at $77.06 \%$; here, the participants mostly used single nouns, phrases, and verbs for the switches. Intra-sentential switching allows for an impression that speakers are inadequately proficient in a language to finish what they want to say. It is a more intimate type than inter-sentential and tag switching since both the code switched segment and those around it must adapt to the syntactic rules of both languages (Poplack 1980). The second most used was tag switching at $15.59 \%$ because they only used this to reassure about some statements or questions related to the student's thesis. The least type used was inter sentential switching at only $7.33 \%$; and this is only used by L3, presumably because to this switch a greater fluency in both languages is required than tag switching since major parts of the utterance must conform to the rules of both languages (Romaine, 1995).

The second research question was on the reasons for code switching, and the results showed that there were 10 functions of code switching from 68 examples in the data. The highest percentage was the function as addressee specification at $22.05 \%$, followed by interjections $(16.17 \%)$, loanwords $(16.17 \%)$, message qualifications $(11.76 \%)$, transfer of the subconscious markers $(8.82 \%)$, proper names $(8.82 \%)$, quotations $(5.88 \%)$, message reiteration $(4.41 \%)$, personalization versus objectification $(2.94 \%)$ and specific features of Islamic terms $(2.94 \%)$ as the least. It can be reasoned that addressee specification was used the most because this was a thesis defense examination and switching to entice attention of the addressee to participate in the conversation is important. Meanwhile, a specific feature of Islamic terms 
Kasim, Yusuf, Ningsih, EduLite: Journal of English Education, Literature, and Culture Vol.4, No.2, August 2019, 101-118 DOI: http://dx.doi.org/10.30659/e.4.2.101-118

was the least used because the first examiner had only used the Arabic greetings in the opening and closing of the examination.

Consequently, Meyerhoff (2006) states that people are equally aware that in some contexts one variety will serve their need better than another. The variety shows different styles of a language that people use depending on where they are, who they are talking to, and what kind of impression that they want to communicate to the other people. As for lecturers, code switching were done for linguistics factor, to continue speaker's pronouncement, addressee specification, information clarification, for intimacy, express feelings, to create humor, repetition used for clarification reiteration of a message, to strengthen request or command, to make questions, to give advice, to balance the addressee's language competence, to make it easier to convey speaker's message, or as discourse markers (Mujiono, et al., 2013). In this case, the student and the lecturers were aware of the need to code switch during the defense examination to make information understandable among them and to ease tension during the oral examination.

\section{CONCLUSION}

It can be concluded that code switching was conducted by all participants, with one of the lecturers conducting the most code switches among them. It can be said that code switching were typically done because of their multilingualism and clarification in getting their messages across to their interlocutors. Because this is a formal session of a final examination prior to a student achieving his degree, thus to gain clarification towards the thesis written, the research conducted, the questions asked and answers given were important so that the examiners could evaluate him efficiently. Any miscommunications can lead to an unsatisfying result of the student. Thus, to thaw the tense atmosphere, there were times when the lecturers would switch and used some jokes in their mother tongue so that the student would not get too stressful with the examination.

As a final point, this research was conducted with a number of limitations. The data were collected only in one thesis defense examination session with five participants in total. Therefore, it is suggested that future research can concentrate on more sessions with more participants to better explain the phenomena of code switching in this topic.

\section{REFERENCES}

Ahmad, B. H., \& Jusoff, K. (2009). Teachers' code-switching in classroom instructions for low English proficient learners. English Language Teaching, 2(2), 49-55.

Berthold, M., Mangubhai, F., \& Batorowicz, K. (1997). Bilingualism \& Multiculturalism: Study Book. Toowoomba: University of Southern Queensland. 
Cook, V. (2001). Using the First Language in the Classroom. Canadian Modern Language Review, 57(3), 402-423.

Creswell, J. W. (2009). Research Design: Qualitative, Quantitative, and Mixed Methods Approaches (3rd Ed.). Los Angeles: Sage Publications, Inc.

Crystal, D. (2003). The Cambridge Encyclopedia of the English Language. Cambridge: Cambridge University Press.

Ellis, R. (1994). The Study of Second Language Acquisition. Oxford: Oxford University Press.

Ibrahim, E. H. E., Shah, M. I. A., \& Armia, N. T. (2013). Code-switching in English as a foreign language classroom: Teachers' attitudes. English Language Teaching, 6(7), 139-150.

Gumperz, J. J. (1982). Discourse Strategies: Studies in Interactional Sociolinguistics. Cambridge: Cambridge University Press.

Hancock, B. (2002). An Introduction to Qualitative Research. Nottingham: Trent Focus Group.

Heller, M. (Ed.). (1988). Codeswitching: Anthropological and Sociolinguistic Perspective. Berlin: Mouton de Gruyter.

Hoffman, C. (1991). An Introduction to Bilingualism. New York: Longman.

Holmes, J. (1992). Learning about Language: An Introduction to Sociolinguistics. London: Longman.

Jamshidi, A., \& Navehebrahim, M. (2013). Learners' use of code switching in the English as a foreign language classroom. Australian Journal of Basic and Applied Sciences, 7(1), 186-190.

Littlewood, W., \& Yu, B. (2011). First language and target language in the foreign language classroom. Language Teaching, 44(1), 64-77.

Macaro, E. (2005). Codeswitching in the L2 classroom: A communication and learning strategy. In Llurda, E. (Ed.), Non-Native Language Teachers: Perceptions, Challenges, and Contributions to the Professions (pp. 63-84). Boston, MA: Springer.

Macaro, E. (2014). Students' strategies in response to teachers' second language explanations of lexical items. The Language Learning Journal, 42(1), 14-32.

McClure, E. (1981). Formal and functional aspects of the code switched discourse of bilingual children. In Duran, R. P. (Ed.), Latino Language and Communicative Behavior (pp. 69-94). Norwood, NJ: Ablex.

Meyerhoff, M. (2006). Introducing Sociolinguistics. London: Taylor \& Francis.

Milroy, L., \& Muysken, P. (1995). One Speaker, Two Languages: CrossDisciplinary Perspectives on Code-Switching. Cambridge: Cambridge University Press.

Mujiono, Poedjosoedarmo, S., Subroto, E., \& Wiratno, T. (2013). Code switching in English as foreign language instruction practiced by the 
Kasim, Yusuf, Ningsih, EduLite: Journal of English Education, Literature, and Culture Vol.4, No.2, August 2019, 101-118 DOI: http://dx.doi.org/10.30659/e.4.2.101-118

English lecturers at universities. International Journal of Linguistics, 5(2), 46-65.

Myers-Scotton, C. (1993). Social Motivations for Codeswitching: Evidence from Africa. Oxford: Clarendon Press.

Numan, D. \& Carter, D. (2001). Teaching English to Speakers of other Languages. Cambridge: Cambridge University Press.

Pillai, S., \& Yusuf, Y. Q. (2012). An instrumental analysis of Acehnese oral vowels. Language and Linguistics, 13(6), 1029-1050.

Poplack, S. (1980). Sometimes I'll start a sentence in Spanish: Y TERMINO EN ESPAÑOL: Toward a typology of code-switching. Linguistics, 18, 581-618.

Ramos, A. L. (2010). Dynamics of code-switching in academic discourse: Evidences for Multilingual Education Bill. CNU Journal of Higher Education, 4(1), 12-23.

Richards, J. C. \& Rogers, T. S. (2001). Approaches and Methods in Language Teaching. Cambridge: Cambridge University Press.

Romaine, S. (1995). Bilingualism (2nd Ed). London: Blackwell Publishing.

Sanchez, B. R. J. (2015). The Dynamics of Social Interaction in Telecollaborative Tandem Exchanges (Doctoral dissertation). University of Iowa, Iowa City, IA.

Skiba, R. (1997). Code switching as a countenance of language interference. Internet TESL Journal. Retrieved from http://iteslj.org/Articles/SkibaCodeSwitching.html

Suan, O. K. (1990). A Study of Code-Switching among Bilingual Malay Students in Certain Urban Secondary Schools (Master's thesis). University of Malaya, Kuala Lumpur.

Wardhaugh, R. (2006). An Introduction to Sociolinguistics (5th Ed.). Malden, MA: Blackwell Publishers.

Yusuf, Y. Q. (2013). A Comparative Study of Vowels in the Acehnese Language Spoken in Kedah, Malaysia and Aceh, Indonesia (Doctoral dissertation). University of Malaya, Kuala Lumpur.

Yusuf, Y. Q. (2009). A pragmatics analysis of a teacher's code switching in a bilingual classroom. The Linguistics Journal, 4(2), 6-39. 